\title{
RESEARCH ON PRAGMATIC MARKERS: DOMAINS AND APPROACHES
}

\author{
Marija Kusevska \\ Goce Delčev University, Štip \\ marija.kusevska@ugd.edu.mk
}

This article was motivated by the need to highlight the various facets of present-day research on pragmatic markers in view of the academic recognition of their importance in conversation. The aim of the paper is twofold. First, it reviews the current literature on pragmatic markers focusing on their definition, classification, functions, and main features as discussed in different theoretical frameworks. The paper also addresses issues that may cause confusion in the study of pragmatic markers, such as word class membership, terminological uncertainty, multifunctionality and domains of application. Second, the paper aims to encourage research on pragmatic markers in Macedonian: in particular to enhance cross-cultural research of these markers by inclusion of other languages and to promote the study of pragmatic markers in the interlanguage of Macedonian learners of foreign languages. The article provides a useful bibliography of the studies on pragmatic markers and refers to major crosscultural and interlanguage studies including those in the field of South Slavic languages.

Key words: core meaning, procedural meaning, indexical function, rhetorical function, multifunctionality 


\title{
ИСТРАЖУВАњЕ НА ПРАГМАТИЧКИТЕ МАРКЕРИ: ТЕНДЕНЦИИ И МЕТОДОЛОГИИ
}

\author{
Марија Кусевска \\ Универзитет „Гоце Делчев“, Штип \\ marija.kusevska@ugd.edu.mk
}

Овој труд е резултат на потребата да се даде преглед на карактеристиките и функциите на прагматичките маркери и да се истакне потребата од научно истражување на нивната употреба во комуникацијата. Трудот има двојна цел. Прво, да даде преглед на современите истражувања на прагматичките маркери со осврт на нивното дефинирање, класифицирање, функциите кои ги извршуваат и нивните карактеристики изложени според различни теориски рамки. Покрај тоа, се разгледуваат и некои прашања кои предизвикуваат забуна во поглед на зборовите групи од кои потекнуваат, терминолошките колебања, повеќефункционалноста и домените во кои се употребуваат. Второ, трудот има за цел да го поттикне истражувањето на прагматичките маркери во Македонија, особено од гледна точка на меѓукултурните прагматички истражувања и истражувањата на меѓујазикот на македонските изучувачи на странски јазици. Трудот содржи значајна библиографија на истражувањата на прагматичките маркери, вклучувајќи и некои истражувања во јужнословенските јазици.

Клучни зборови: основно значење, процедурално значење, индексирање, реторички функции, повеќефункционалност 


\section{What are pragmatic markers?}

Pragmatic markers are very common in spoken language. Conversations in all languages abound in words such as yeah, right, well, I mean, like, you know that speakers use to achieve a smooth flow of speech and help their interlocutors decode the meaning of their utterances appropriately. They are linguistically encoded clues which signal the speaker's potential communicative intention (Fraser 1996: 168). Speakers also use them to modify the strength of their utterances or mitigate facethreatening acts.

All researchers who have investigated pragmatic markers agree that these elements facilitate spontaneous speech production and interaction and prevent the speaker from being seen as impolite or awkward. Crystal describes them as "the oil which helps us perform the complex task of spontaneous speech production and interaction smoothly and efficiently." (Crystal 1988, in Müller, 2005: 1). There is disagreement, however, on how to call them and how to treat them. Crible (2018), who is more interested in the cognitive processes, labels well and you know as discourse markers, while Beeching (2016), who is more interested in their sociolinguistic, interactional quality, calls them pragmatic markers. Other contesting terms for their role are discourse particles, pragmatic particles, pragmatic expressions, connectives.

\section{Discourse markers (DM) or pragmatic markers (PM)?}

Schiffrin (1987: 31) uses the term discourse markers including oh, well, and, but, or, so, because, now, then, I mean, y'know and describes them as "sequentially dependent elements which bracket units of talk." They are closely related to discourse coherence, i.e., "how speakers and hearers jointly integrate forms, meanings, and actions to make overall sense out of what is said." (Schiffrin 1987: 49). Jucker and Ziv (1998: 1) also use the term discourse markers and explain that the terminological diversity is due to the wide range of linguistic approaches that have been used for their study, and the multiplicity of functions that they fulfill.

Similarly, Degand and Simon-Vandenbergen (2011: 287) adopt the term discourse marker after relating "the term grammaticalization to the processes which have led to the emergence of the words which are generally labeled discourse markers, discourse particles or pragmatic markers." Many other researchers opted for the term 'discourse marker' (Blakemore 2002; Crible 2018; House 2013; Müller 2005). Crible (2018) ascribes this terminological problem to the changing nature of language in general, to the fuzziness of semantics and the variation of discourse in particular. It is also caused by the many different frameworks within which this category has been investigated throughout the years, diverging either on theories, 
research agendas, methods or data types (Crible 2018). In order to provide more specific criteria for DM identification, Crible proposes the following definition:

DMs are a grammatically heterogeneous, syntactically optional, polyfunctional type of pragmatic marker. Their specificity is to function on a metadiscursive level as procedural cues to constrain the interpretation of the host unit in a cobuilt representation of on-going discourse. They do so by either signaling a discourse relation between the host unit and its context, making the structural sequencing of discourse segments explicit, expressing the speaker's metacomment on their phrasing, or contributing to the speaker-hearer relationship. (Crible 2018: 34)

Aijmer and Simon-Vandenbergen (2006, 2009), on the other hand, prefer the term 'pragmatic marker' to 'discourse marker'. They describe discourse markers as particular markers signaling coherence relations, and pragmatic markers as markers not only associated with discourse and textual functions but also as signals guiding the addressee's interpretation. Aijmer (2011) also accepts this term and classifies well, you know, I mean, sort of as pragmatic markers. Fraser (2009) defines pragmatic markers as "free morphemes which are proposition-initial, signal a specific message either about or in addition to the basic message, and are classified as pragmatic markers by virtue of their semantic/pragmatic functions." $\mathrm{He}$ classifies them in four groups: (a) basic pragmatic markers (performative verbs, please); (b) commentary pragmatic markers (assessment markers, manner-ofspeaking markers, evidential markers, hearsay markers, (non)deference markers); (c) discourse markers (typically signal a relation between the discourse segment which hosts them and the prior discourse segment, perhaps produced by another speaker (contrastive, elaborative, inferential DM); (d) discourse structure markers (discourse management markers, topic orientation markers, attention markers). $\mathrm{He}$ thus uses the term 'pragmatic marker' as an umbrella term that encompasses both discourse markers and pragmatic markers, considering discourse markers as a subtype of pragmatic markers, and referring particularly to expressions which signal the relationship of the basic message to the discourse which precedes it. In his description of discourse markers, Fraser (2009: 297) states that "[f]or an expression to be a DM it must be acceptable in the sequence S1-DM+S2, where S1 and S2 are discourse segments, each representing an Illocutionary Act." Beeching (2016: 3) has a similar understanding and states that "[a] consensus appears to be emerging with respect to the ways in which pragmatic markers might be said to be distinguishable from both discourse markers (DMs) and connectives, and to delineate their multifunctional role in social interaction."

Hansen (2006 in Crible 2018) also assigns to PM the status of an umbrella category with a much broader scope, including DMs:

Discourse marker should be considered a hyponym of pragmatic marker, the latter being a cover term for all those non-propositional functions which linguistic items may fulfill in discourse. Alongside discourse markers, whose 
main purpose is the maintenance of what I have called "transactional coherence", this overarching category of functions would include various forms of interactional markers, such as markers of politeness, turn-taking etc. whose aim is the maintenance of interactional coherence; performance markers, such as hesitation markers; and possibly others. (Hansen 2006 in Crible 2018: 34)

In this view, pragmatic markers include various procedural elements such as "connectives, modal particles, pragmatic uses of modal adverbs, interjections, routines (how are you), feedback signals, vocatives, disjuncts (frankly, fortunately), pragmatic uses of conjunctions (and, but), approximators (hedges), reformulation markers" (Aijmer and Simon-Vandenbergen 2011, in Crible 2018: 34).

We would conclude this section with our observation that the term 'discourse marker' is preferred when the marker in focus is 'sequentially dependent' (Fraser 1996, 1999, 2009; Schiffrin 1987), while the term 'pragmatic marker' prevails when the focus is on their pragmatic function, i.e., when they mark illocutionary force or have an interactional function. As our interest is focused on the sociolinguistic, interactional facet of these terms rather than their logical connective properties, we will use the term pragmatic markers, although other terms will be used when referring to certain authors.

\section{Functions of pragmatic markers}

While pragmatic markers are semantically empty and can be dropped without affecting the meaning of a sentence, they serve a variety of functions. If such markers are omitted, the discourse is grammatically acceptable, but would be judged 'unnatural', 'awkward', 'disjointed', 'impolite', 'unfriendly', or 'dogmatic' within the communicative context (Brinton 1996). For Beeching (2016: 4) pragmatic markers, being most frequent in spoken language constitute a fundamental part of oral fluency. She points out five main ways in which the particular characteristics of conversation are reflected in the usages of pragmatic markers:

1. Conversation is spontaneous and takes place at speed; unlike writing, there is no opportunity for speakers to edit what they say before 'publication'; pragmatic markers allow for hesitation, back-tracking, repair and repetition.

2. Conversation is interactional; pragmatic markers occur at the junction between speakers in turn-taking, frequently in utterance-initial or utterance-final positions.

3. Conversation is social; pragmatic markers may be sociolinguistically marked (used in particular regions, by speakers of particular age-groups or particular social groups). 
4. Conversation is sociable; pragmatic markers are often associated with naturalness, friendliness and warmth. In addition, they are often addressee oriented: they allow the addressee's opinion to be enjoined or invoked.

5. Conversation is polite; pragmatic markers can hedge talk, downtoning what might be considered over-strong assertions of opinion.

Aijmer (2013) describes pragmatic markers as 'surface phenomena' while "the speaker's cognitive processes are hidden to observation. However, pragmatic markers (and other devices) can emerge as overt indicators of (or windows on) ongoing metalinguistic activity in the speaker's mind." They are reflexive i.e., they 'mirror' the speaker's mental processes and comment on what goes on in the speaker's mind (Redeker 2006, in Aijmer 2013: 4). The reflexivity of pragmatic markers is expressed through their indexical and rhetorical functions. PM may have several functions as indexicals, i.e., as monitors of the progress of the action: they point to the planning going on in the speaker's mind or accompany processes such as reformulation or revision (1); they announce a new or change of the topic (2); or they may indicate ending or taking the turn (3).

(1) People always start by saying... well ... I'm not saying that the president did anything wrong. (CNN Crossfire, June 2, 2005)

(2) A: So what's the climax of our show?

B: Show? You don't have a show.

A: We have a week's engagement.

B: To perform magic, not butcher birds and break my customers' fingers. (from the film The Prestige)

(3) A: Julia, you got home very late last night.

B: Oh dad, are you kidding? It was only $11 \mathrm{pm}$ !

A: Yes, but it was a school night. I saw you were late for school this morning.

B: Dad, I'm already sixteen, and I didn't go to the first class because it's easy.

A: Well Julia, I definitely do not want you skipping classes, no matter what! Is that clear?

Markers with predominant rhetorical functions signal the speaker's intentions and goals and help convey the intended meaning. They are not used randomly in communication but are context and genre dependent. In his study on narratives, Gonzalez (2005) finds out that most functions that pragmatic markers fulfill in this genre are rhetorical, such as introducing a comment, clarifying, concluding, emphasizing, evaluating, resuming topic, etc. Rhetorical functions, also enable speakers to take up a stance, for example agreeing or disagreeing with what is said, 
as in (4) and (5). This makes pragmatic markers contextualizing cues pointing to the text type or the situation they are found in.

(4) wel $-==^{1}$. i don't know about that. because that would suggest that $=-\mathrm{i}$ mean $==\left(\mathrm{MRDA}^{2}\right)$

(5) yeah but that's - that's just shifting the problem. then you would have to make a decision (MRDA)

It is worth pointing out that there is a general agreement among researchers that markers have a procedural rather than conceptual/declarative meaning. They participate in inferential processes that help interpret an utterance (Blakemore 2002) and bring something to the attention of the hearer. In Blakemore's example New York was the windiest city in the United States today, but Chicago had light winds (Blakemore 2002: 102), but performs an inference which results in the contradiction and elimination of an assumption. The assumption that is contradicted here is that Chicago is the windiest city in the USA. Well, on the other hand, is more elusive and is found in different contexts. It may precede a question or an answer (6), or it may introduce a counter argument, a denial, a refusal (7-8), etc.

(6) Well what are we doing now?

(7) A: Shall we try that restaurant? I hear the food is good.

B: Well the food is good but expensive. I need to save some money.
A: Do you want to take over from her?
B: Well I don't seem to be prepared to do it.

Andersen (2001) describes the functions of pragmatic markers as subjective, interactional and textual. The subjective functions of pragmatic markers make explicit the attitude of the speaker towards the proposition expressed in the utterance. It comprises a number of different types of meaning, such as speaker's epistemic stance, his/her affective attitude and evaluation of the newsworthiness of the propositional content. Examples of pragmatic markers conveying these types of meaning are I guess, I mean, absolutely, sort of, in fact, of course, apparently etc. The interactional functions reveal "the speaker's inclination to take the hearer's perspective in evaluating propositional meaning" (Andersen 2001: 69). They are hearer-oriented and their typical representatives are you know and right?. The interactional function of pragmatic markers may also be associated with social

\footnotetext{
${ }^{1}$ Symbols used in the transcriptions: = short lengthening; = = long lengthening; - short pause; - - long pause; ... long pause

${ }^{2}$ MRDA stands for Meeting Recorder Dialogue Act. It is a project corpus of 72 hours of speech from 75 naturally-occurring meetings, Copyright (C) 2004 International Computer Science Institute.
} 
functions such as the expression of solidarity and politeness. The textual functions of pragmatic markers, on the other hand, refer to their role of contributing to coherence in discourse. Some pragmatic markers, e.g., well, are multifunctional and may cover some or all of the functions. On the other hand, and has predominantly textual functions. Andersen (2001: 81) therefore concludes that PM "can be primarily associated with one of the three functional levels; that is to say, some markers are predominantly textual, others predominantly subjective and yet others predominantly interactional."

Brinton's description (1996: 37-38) of the functions of the pragmatic markers is more elaborate including the list of functions presented below.

a) to initiate discourse, including claiming the attention of the hearer, and to close discourse;

b) to aid the speaker in acquiring or relinquishing the floor;

c) to serve as a filler or delaying tactic used to sustain discourse or hold the floor;

d) to mark a boundary in discourse, that is, to indicate a new topic, a partial shift in topic (correction, elaboration, specification, expansion), or the resumption of an earlier topic (after an interruption);

e) to denote either new information or old information;

f) to mark "sequential dependence", to constrain the relevance of one clause to the preceding clause by making explicit the conversational implicatures relating the two clauses, or to indicate by means of conventional implicatures how an utterance matches cooperative principles of conversation;

g) to repair one's own or others' discourse;

h) subjectively, to express a response or a reaction to the preceding discourse or attitude towards the following discourse, including also back-channel signals of understanding and continued attention spoken while another speaker is having his or her turn and perhaps: hedges expressing speaker tentativeness; and

i) interpersonally, to effect cooperation, sharing, or intimacy between speaker and hearer, including confirming shared assumptions, checking or expressing understanding, requesting confirmation, expressing deference, or saving face.

The functions listed above fall into two categories described by Halliday (1976: 29), "the first set $(\mathrm{a}-\mathrm{g})$ belonging to the 'textual' mode of language and the second set ( $\mathrm{h}-\mathrm{i})$ belonging to the 'interpersonal' mode" (Brinton 1996: 39). Halliday's third mode represents the ideational mode: the content. Although Halliday is sometimes criticized for integrating all three modes within the grammar of language (Leech 1983, in Brinton 1996), they are used in most taxonomies of DM.

Fraser (1996) assumes that sentence meaning can be divided into two distinct parts: propositional or content meaning and non-propositional meaning. His 
classification of pragmatic markers is given in Section 2. The propositional, i.e., ideational content includes temporal sequence, elaboration, cause, reason, consequence etc (Redeker 1990). The second meaning includes different types of signals, i.e., pragmatic markers, which correspond to different types of potential direct messages a sentence may convey. Their function is to encode clues which signal the speaker's potential communicative intention. Redeker (1990) distinguishes rhetorical relations and sequential relations. The former cover antithesis, concession, evidence, justification, conclusion, and so forth, while sequential relations include transitions to the next topic or to the next point, introduction of a commentary, correction, paraphrase, digression, or interruption segment. Crible (2018: 98) likewise distinguishes four domains, namely ideational (content, objective relations), rhetorical (speaker's attitude, subjective relations), sequential (turn exchange and topic structure) and interpersonal (speaker-hearer relationship).

In addition to the above functions, Beeching (2016: 17) relates pragmatic markers to politeness. They can modify an utterance or express solidarity because "they hint at uncertainty or approximativeness, and because they are often associated with naturalness, friendliness and warmth" and when it comes to politeness, ambiguity can be very useful. This makes pragmatic markers very important for interactional sociolinguistics. They enable speakers to decrease the formality of their speech-style thereby creating intimacy and making their addressees feel more comfortable. Therefore, pragmatic markers may be regarded as an instrument of both positive and negative politeness.

\section{Basic features of pragmatic markers}

In this section we present an overview of the basic features of pragmatic markers.

\section{No single word class}

Pragmatic markers do not make up a single, well-defined grammatical class, but come from different word classes. Fung and Carter (2007) list the following features to indicate the range: coordinate conjunctions (and, but, or), subordinate conjunctions (since, because, so), prepositional phrases (as a consequence, in particular, by the way, at the end of the day); adverbs (now, actually, anyway, obviously, really, certainly, absolutely). minor clauses (you see, I mean, you know); response words (yeah, yes, no); interjections (oh, ah, well); metaexpressions (this is the point, what I mean is, that is to say, in other words). 


\section{No conceptual/propositional meaning}

This is perhaps their most significant characteristic. Most linguists agree that PM do not contribute to the propositional meaning of a sentence.

On the one hand, a sentence typically encodes a proposition, perhaps complex, which represents a state of the world which the speaker wishes to bring to the addressee's attention. This aspect of sentence meaning is generally referred to as the propositional content (or content meaning) of the sentence. On the other hand, there is everything else: Mood markers such as the declarative structure of the sentence, and lexical expressions of varying length and complexity. (Fraser 1996: 167)

Pragmatic markers belong to that group of 'everything else' and their meaning depends on the context in which they are produced. This may be the reason why their meaning and their functions are not obvious. Speakers find them vague and difficult to explain. When Macedonian speakers are asked about the meaning of the PM $n a$ (pa) 'well, but' their initial reaction is that it means nothing, but upon giving it some thought they become aware that it may signal disagreement or agreement, mark speaker's insecurity or assertiveness, or just intensify an adjacent marker (Kusevska 2014).

Andersen (2001: 41) argues that "some pragmatic markers clearly have conceptual meanings, for instance I mean, you know, I guess and so on" and that they are "a synthesis of linguistically encoded and pragmatically inferred material" due to their grammaticalisation. Still, he points out that it is only a small number of pragmatic markers that are problematic with respect to being propositional or nonpropositional, and that many pragmatic markers are non-propositional.

\section{Combining PM}

One of the most salient features of PM in all languages is their short form and high frequency in oral discourse. Moreover, they tend to group in an utterance as in Well, anyway, I mean, what was the reason ... y'know, why did she do it, anyway? (Brinton 1996: 33). In Macedonian, almost every new utterance begins with a PM and we may find clusters consisting of up to five PM as in E па сега гледај ваму 'Well now look here'. However, the principle behind the combination and the function of each cluster member remains unclear. This characteristic of PM is severely understudied except in the works of some scholars such as Fraser (2013, 2015), who explores the combinations of contrastive discourse markers in English (but, on the other hand), combinations of inferential discourse markers (so, as a result), and combinations from different classes (but, as a result; so, instead). His results show that it is quite possible to have intra-class combinations of contrastive DM (We could go for a walk. But, on the other hand, we could stay home and watch $T V$ ). However, combinations of inferential DM are fewer (The bridge was out. 
Thus, as a result, we had to turn back), and even less frequent are cross-class combinations.

\section{Relation to politeness}

Pragmatic markers are also related to both positive and negative politeness. Coates (2013, in Beeching 2016: 12) points out that hedging pragmatic markers are a valuable resource as they allow speakers to avoid commitment, find the right words, facilitate open discussion and qualify assertions. On the one hand, PM hint at uncertainty or approximativeness, but on the other, they are often associated with naturalness, friendliness and warmth. As such, they support both positive and negative politeness. However, PM are socially stigmatized as speakers often view them negatively. They tend to manifest a negative attitude towards a certain marker and claim that they never use it. Such is the case with the Macedonian marker $\sigma e$ $(\text { be })^{3}$ which is used as a solidarity marker. Being very informal and intimate it is widely used with close friends, although its use seems to be on the rise because it decreases formality or/and generates a number of implicit meanings. It may create a comical effect though when foreigners use it. ${ }^{4}$ The examples provided below were taken from a semi-formal conversation in which one of the participants becomes more assertive by decreasing the distance:

(9) Евтини се бе.

'They are really cheap be.'

(10) Одговараат бе.

'They are okay be.'

(11) И деиата ги сакаат бе.

'Children also like them be.'

Pragmatic markers are often associated with informality and with women's speech. In relation to women's speech in British English, Coates (2013, in Beeching 2016: 12) found that in 40 minutes of speech in narratives told by women and men, women use more hedging pragmatic markers than men do, 316 and 166 respectively. Beeching (2016: 12) argues that "hedging pragmatic markers are used more in women's talk because women engage in a type of self-disclosing discourse which encourages their use." As such, they index 'femaleness'. The indexical function of PM has been generally accepted (Andersen 2001; Beeching 2016;

\footnotetext{
${ }^{3}$ Pronounced as the first syllable in Betty.

${ }^{4}$ When a student of mine learning Macedonian used it with some of her friends, native speakers of Macedonian, they laughed at her and advised her against using it with other people.
} 
Brinton 1996; Gonzales 2005); for instance. like points to young people and you know points to common ground.

\section{Syntactic features}

PM are optional, loosely attached to the syntactic structure and an utterance is still grammatical if they are dropped. They do not enter into grammatical relations with other elements of the sentence (Andersen 2001; Jucker and Ziv 1998; Müller 2005). Although their usual position is the beginning of an utterance, they may be also found in other positions, especially final (Brinton 1996; Fraser 1999; Schiffrin 1987). Crible (2018: 92) also notes that "in interactive settings, where DMs do occur at the beginning or end of turns (e.g., conversations), turn-initial DMs are always more frequent than turn-final DMs, which suggests a more prominent role of DMs in taking a turn (and holding it turn-medially) rather than giving it away."

(12) P: there there is uh one week where the building companies come to to to the university and they make some presentation and $=$ $\mathrm{S}:=$ ahh this week yeah P: this one week erm yeah but I cannot do it I have to go here this week S: yeah the week of civil engineering yeah (House 2013: 61)

(13) the larger you get you can therefore make economies of scale (Crible 2018: 94)

(14) I was happy... sort of! (Crible 2018: 96)

(15) We don't have to go. I will go, nevertheless. (Fraser 1999: 8)

\section{Multifunctionality}

Beeching (2016: 6) calls PM "notoriously both polysemous and multifunctional," which poses problems of interpretation. Pragmatic markers can point both backward or forward to project a new turn. They can also introduce a narrative, an argument or a description. Found in different linguistic contexts they can have different functions depending on whether they occur in questions or answers. Besides, they can point to the planning going on in the speaker's mind or function as a politeness marker. As Andersen (2001) points out, multifunctionality is rather a rule than an exception. Markers are not only multifunctional in the sense that they can serve different pragmatic functions in different contexts, but they can also have several pragmatic features at the same time. For instance, it is difficult to decide if well in (16) is a starter, a hesitator or a politeness marker, and whether like in (17) is a hesitator (and false starter) or it marks an approximate number, introduces an explanation or highlights an expression. 
(16) B: but i think it's a little bit more complex. as - if i understand it correctly it always gives you all the posterior probabilities for all the values of all decision nodes. so when we input something we always get the uh posterior probabilities for all of these.

A: let's look at an example.

B: well w- - wouldn't we just take the structure that's outputted and then run another transformation on it that would just dump the one that we wanted out? (MRDA)

(17) $\mathrm{C}:$ um $\mid$ yeah but there's like a certain level of $==$

$\mathrm{B}$ : there's a bandwidth issue. right?

C: well that's a - a question mark. um $==$ just $u h==$ that's way beyond their scope is - of interpreting that. you know. but um $==$ still outcome $\mathrm{w}-$ - the outcome will be some form of structure. (MRDA)

However, some discourse markers are restricted to certain contexts or styles. Beeching (2016: 14) points out that "there appears to be far greater variation in usage of markers with respect to communicative functions and to situations than with respect to social class, gender or age." For example, individual markers have particular roles to play in conjunction with particular speech acts. Contrastive markers such as but are typical for disagreement, please is used in requests to soften the imposition, while I think is used in complaints and argumentative talks to decrease the assertoric force.

\section{Research of PM}

As far as English is concerned, the number of studies on pragmatic markers is impressive. The frameworks of research for pragmatic or discourse markers are primarily motivated by linguists' interest in discourse coherence (Schiffrin 1987), their pragmatic role (Fraser 1999, 2009) and theory of relevance (Blakemore 2002). Research of pragmatic markers has been enabled by compilation of language corpora that provides researchers with a wide scope of data and technical possibilities for searching through them. Corpora make it possible to investigate the distribution of pragmatic markers in speech and writing in different registers (Aijmer 2013; Beeching 2016; Fischer 2006). Most of these studies are concerned with the use of pragmatic markers in modern English. Intra-linguistic studies often focus on one marker such as well (Aijmer 2013; Beeching 2016; Jucker 1993; Schiffrin 1987), but (Blakemore 2012; Holtgraves 1997), actually (Aijmer 2013), like (Andersen 2001; Beeching 2016), anyway (Park 2010), or compare several markers on the basis of their similarity or differences (Bell 2010; Blakemore 2012; Simon-Vandenbergen 2008). 
Parallel and other comparable corpora create oportinities for studying pragmatic markers cross-linguistically (Aijmer and Simon-Vandenbergen 2006; Crible 2018; Cuenca 2008; Gonzales 2005; Jucker and Ziv 1998; Mortier and Degand 2009), while learner corpora shed light on how language learners use pragmatic markers (Aijmer 2011; Aijmer 2004; Beeching and Woodfield 2015; Fung and Carter 2007; Hellermann and Vergun 2007; House 2013; Müller 2005; Polat 2011). Yet research on translation of pragmatic markers has received only limited attention. Blakemore and Gallai (2013) look at how relevance theory accounts for "the role of perspective dependent discourse markers such as well in the relevance theoretic model of communication in cases where the perspective they are linked to is not that of the speaker who uses them". Their focus is on the use of so and well by interpreters. They are primarily concerned with examples of interpreted data in which the interpreter adds a discourse marker not found in the original and with cases in which discourse markers found in the original are not translated by the interpreter. Peterlin and Moe (2016) have studied translation of hedging devices in news discourse. Their paper investigates the translator's performance in translating hedges as well as his/her perception of their pragmatic role in journalistic texts. The analysis reveals that translators often omit or modify them.

In spite of their frequency, these pragmatic markers have not attracted due attention of the researchers working on Macedonian and other South Slavic languages. Here I would like to mention Dedaić and Mišković-Luković (2010: 1) whose aim was "to fill the lacuna in the current scholarship on particles in South Slavic, and to contribute to a better understanding of the semantic meaning and pragmatic roles of these communicative vehicles par excellence." It comprises several studies of discourse markers in Macedonian, Serbian, Bulgarian, Slovenian, Bosnian and Croatian. Other individual efforts include Dedaić (2005), Fielder (2008), Mišković (2001), Tchizmarova (2005), Venovska-Antevska (ВеновскаАнтевска 2003), Buzarovska (Бужаровска 2014), Kusevska (Кусевска 2012, 2014).

\section{Conclusion}

In this paper we present an overview of issues related to research of pragmatic markers with a special emphasis on their definition, classification, functions and main features. The paper also addresses possible points of confusion in the study of pragmatic markers, such as word class membership, terminological uncertainty, multifunctionality and domains of functioning. Referring to major studies in this field, we discuss key theoretical frameworks and current achievements and show that pragmatic markers open a new ground for investigating the use of language in communication. Maintaining that the research of pragmatic markers deepens our understanding of language, culture and communication, the paper highlights the need of such studies in the realm of contrastive and interlanguage pragmatics. 


\section{References}

Aijmer, K. (2004). Pragmatic markers in spoken interlanguage. Nordic Journal of English Studies, 3: 173-190.

Aijmer, K. (2011). Well I'm not sure I think... The use of well by non-native speakers. International Journal of Corpus Linguistics, 16 (2): 231-254.

Aijmer, K. (2013). Understanding pragmatic markers: A variational pragmatic approach. Edinburgh: Edinburgh University Press.

Aijmer, K. and Simon-Vandenbergen, A.-M. (eds.). (2006). Pragmatic markers in contrast. Oxford/Amsterdam: Elsevier Ltd.

Aijmer, K. and Simon-Vandenbergen, A.-M. (2009). Pragmatic Markers. In J.-O. Östman and J. Verschueren (eds.). Handbook of pragmatics, 223-247. Amsterdam/Philadelphia: John Benjamins.

Andersen, G. (2001). Pragmatic markers and sociolinguistic variation: A relevancetheoretic aproach to the language ofaAdolescents. Amsterdam/Philadelphia: John Benjamins.

Beeching, K. (2016). Pragmatic markers: Meaning in social interaction. Cambridge: Cambridge University Press.

Beeching, K. and Woodfield, H. (eds.) (2015). Researching sociopragmatic variability. New York: Palgrave Macmillan.

Bell, D. M. (2010). Nevertheless, still and yet: Concessive cancellative discourse markers. Journal of Pragmatics, 42: 1912-1927.

Blakemore, D. (2002). Relevance and linguistic meaning : The semantics and pragmatics of discourse markers. Cambridge: Cambridge University Press.

Blakemore, D. and Gallai, F. (2014). Discourse markers in free indirect style and interpreting. Journal of Pragmatics, 60: 106-120.

Brinton, L. J. (1996). Pragmatic markers in English. Berlin: Mouton de Gruyter.

Crible, L. (2018). Discourse markers and (dis)fluency. Amsterdam/Philadelphia: John Benjamins.

Cuenca, M.-J. (2008). Pragmatic markers in contrast: The case of well. Journal of Pragmatics, 40: 1373-1391.

Dedaić, M. N. (2005). Ironic denial: Toboze in Croatian political discourse. Journal of Pragmatics, 37: 667-683.

Dedaić, M. N. and Mišković-Luković, M. (eds). (2010). South Slavic discourse particles. Amsterdam/ Philadelphia: John Benjamins.

Degand, L. and Simon-Vanderbergen, A.-M. (2011). Introduction: Grammaticalization and (inter)subjectification of discourse markers. Linguistics, 49 (2): 287-294.

Fielder, G. (2008). Bulgarian adversative connectives: Conjunctions or discourse markers? In R. Laury (ed.), Crosslinguistic studies of clause combining, 79-97. Amsterdam/Philodalphia: John Benjamins.

Fischer, K. (ed.) (2006). Approaches to discourse particles. Oxford/Amsterdam: Elsevier. Fraser, B. (1996). Pragmatic markers. Pragmatics, 6 (2): 167-190. 
Fraser, B. (1999). What are discourse markers? Journal of Pragmatics, 31: 931-952.

Fraser, B. (2009). An account of discourse markers. International Review of Pragmatics, 1: 293-320.

Fraser, B. (2013). Combinations of contrastive discourse markers in English. International Review of Pragmatics, 5: 318-340.

Fraser, B. (2015). The combining of discourse markers: A beginning. Journal of Pragmatics, 86: 48-53.

Fung, L. and Carter, R. (2007). Discourse markers and spoken English: Native and learner use in pedagogic setting. Applied Linguistics, 28 (3): 410-439.

Gonzalez, M. (2005). Pragmatic markers and discourse coherance relations in English and Catalan oral narrative. Discourse Studies, 7 (1): 53-86.

Halliday, M.A.K. and Hasan, R. (1976). Cohesion in English. London: Longman.

Hellermann, J. and Vergun, A. (2007). Language which is not taught: The discourse marker use of beginning adult learners of English. Journal of Pragmatics, 39: 157-179.

Holtgraves, T. (1997). Yes, but ... Positive politeness in conversation arguments. Journal of Language and Social Psychology, 16: 222-239.

House, J. (2013). Developing pragmatic competence in English as a lingua franca: Using discourse markers to express (inter)subjectivity and connectivity. Journal of Pragmatics, 59: 57-67.

Jucker, A. H. (1993). The discourse marker well: A relevance-theoretical account. Journal of Pragmatics, 19: 435-452.

Jucker, A. H. and Ziv, Y. (eds.). (1998). Discourse markers: Description and theory. Amsterdam/Philadelphia: John Benjamins.

Miškovć, M. (2001). The particle baš in contemporary Serbian. International Pragmatics Association 11 (1), 17-30.

Mortier, L. and Degand, L. (2009). Adversative discourse markers in contrast. International Journal of Corpus Linguistics, 14 (3): 301-329.

Müller, S. (2005). Discourse markers in native and non-native English discourse. Amsterdam/ Philadelphia: John Benjamins.

Park, I. (2010). Marking an impasse: The use of anyway as a sequence-closing device. Journal of Pragmatics, 42: 3283-3299.

Peterlin, A. P. and Moe, M. Z. (2016). Translating hedging devices in news discourse. Journal of Pragmatics, 102: 1-12.

Polat, B. (2011). Investigating acquisition of discourse markers through a developmental learner corpus. Journal of Pragmatics, 43: 3745-3756.

Redeker, G. (1990). Ideational and pragmatic markers of discourse structure. Journal of Pragmatics, 14: 367-381.

Schiffrin, D. (1987). Discourse markers. Cambridge: Cambridge University Press.

Simon-Vandenbergen, A.-M. (2008). Almost certainly and most definitely: Degree modifiers and epistemic stance. Journal of Pragmatics, 40: 1521-1542.

Tchizmarova, I. K. (2005). Hedging functions of the Bulgarian discourse marker xajde. Journal of Pragmatics, 37: 1143-1163. 
Бужаровска, Е. (2014). Глаголите за перцепција како прагматички маркери во македонскиот и во рускиот јазик. Руско-македонски јазични, литературни и културни врски, книга 5, 83-92. Скопје: Филолошки факултет, УКИМ.

Веновска-Антевска, С. (2003). Сврзникот 'но' во македонскиот јазик: дијахронија, синхронија, перспективи. Скопје: Институт за македонски јазик.

Кусевска, М. (2012). Дискурсниот маркер ама: прагматичка анализа на неговата употреба во говорните чинови на несогласување. Македонски јазик, 63: 104-119.

Кусевска, М. (2014). Улогата на па како адверсативен дискурсен маркер. Македонски јазик, 65: 253-264. 